\title{
Pengaruh Kompetensi Profesional Dan Kompetensi Pedagogik Terhadap Kinerja Guru Ekonomi SMA Negeri Di Kota Bandung
}

\author{
Raden Roro Suci Nurdianti \\ Jurusan Pendidikan Ekonomi Universitas Siliwangi \\ Jl. Siliwangi No.24 Tasikmalaya, Tasikmalaya Jawa Barat, Indonesia \\ E-mail: radenrorosucinurdianti@unsil.ac.id
}

\begin{tabular}{c}
\hline Article Info \\
\hline Received: \\
1 Oktober 2017 \\
Revised: \\
20 Oktober 2017 \\
Accepted: \\
29 Oktober 2017 \\
\hline
\end{tabular}

\begin{abstract}
ABSTRAK
Penelitian ini untuk menganalisis mengetahui pengaruh Kompetensi Profesional dan Kompetensi Pedagogik terhadap Kinerja guru Ekonomi yang terdapat di SMA Negeri di Kota Bandung. Populasi dalam penelitian yaitu guru ekonomi di SMA Negeri Kota Bandung. Metode penelitian yang digunakan dalam penelitian ini yaitu survei eksplanatori, sedangkan pengambilan sampel dilakukan melalui metode simple random sampling, sehingga didapatkan sebanyak 90 guru ekonomi. Data diperoleh dari data primer dan data sekunder melalui angket dan informasi dari pihak sekolah. Hasil penelitian menunjukan Kompetensi Profesional dan Kompetensi Pedagogik secara signifikan mempengaruhi Kinerja guru ekonomi di SMA Negeri di Kota Bandung.
\end{abstract}

Kata Kunci: Kompetensi Profesional, Kompetensi Pedagogik, Kinerja

\section{The influence of professional competence and pedagogic competence on the performance of economic teachers at SMA Negeri in Bandung City}

\begin{abstract}
This study aims to analyze the influence of professional competency and pedagogical economic performance of teachers in high schools of Bandung City. The population in this research is economic teachers in public senior high schools of Bandung City. Methods that were used in this research is the explanatory survey methods, while the sample collection was undertaken through a method of simple random sampling, so we get 90 economic teachers as a sample. Data collected from primary and secondary data through information from the school.The results of the study show professional competency and pedagogical significantly influences the performance of economic teachers in high schools in the city of Bandung.
\end{abstract}

Keywords: Professional Competencies, Pedagogical Competencies, Performance

How to cite:

Raden, R. S.N. (2017). Pengaruh Kompetensi Profesional Dan Kompetensi Pedagogik Terhadap Kinerja Guru Ekonomi SMA Negeri Di Kota Bandung. Jurnal Ilmiah Manajemen \& Bisnis, 18(2), 177-188. 


\section{PENDAHULUAN}

Peranan guru sangat menentukan dalam usaha peningkatan kualitas pendidikan formal. Sebagai agen pembelajaran, guru dituntut untuk mampu menyelenggarakan proses pembelajaran dengan sebaik-baiknya, dalam kerangka pembangunan pendidikan. Guru mempunyai fungsi dan peran yang sangat strategis dalam pembangunan bidang pendidikan, dan oleh karena itu perlu dikembangkan sebagai profesi yang bermartabat. Undang-Undang No. 14 tahun 2005 tentang Guru dan Dosen Pasal 4 menegaskan bahwa guru sebagai agen pembelajaran berfungsi untuk meningkatkan mutu pendidikan nasional, sehingga untuk dapat melaksanakan fungsinya dengan baik, guru wajib untuk memiliki syarat tertentu, salah satu di antaranya adalah kompetensi. Menurut Mulyasa (2011), secara professional karakteristik guru yang dinilai adalah harus mampu bertanggungjawab dengan baik, menjalankan peran dan fungsi guru dengan tepat, mampu bekerja untuk mewujudkan tujuan pendidikan di sekolah dalam pembelajaran di kelas.

Kebanyakan studi mengenai kompetensi guru lebih berfokus kepada peranan guru di dalam kelas dibandingkan kompetensi guru itu sendiri. Kompetensi guru telah diperluas dengan reformasi Pendidikan, pengembangan Pendidikan guru, hasil ilmiah dalam ilmu Pendidikan, dan bidang-bidang lainnya. (Selvi, 2010). Pada dasarnya terdapat empat kompetensi yang harus dimiliki oleh seorang guru, diantaranya Kompetensi Pedagogik, Kompetensi Profesional, Kompetensi Sosial, dan Kompetensi Pribadi (Rusman, 2012). Dari keempat kompetensi yang harus dimiliki oleh guru, keseluruhannya menunjang satu sama lain dalam penciptaan proses pembelajaran yang efektif. Pada dasarnya, guru lah yang memegang kunci keberhasilan pencapaian hasil belajar siswa sehingga keempat kompetensi tersebut harus benar-benar dikuasai oleh guru, terutama berkaitan dengan kompetensi yang menentukan penguasaaan kelas guru. Penguasaan kelas ini sangat berkaitan dengan kompetensi pedagogik, dan juga ditunjang oleh kompetensi professional guru yang bersangkutan. Kualitas kompetensi mengajar memegang peranan penting dalam penciptaan dan penetapan kualitas proses pembelajaran bagi siswa, dan juga menunjukkan tingkat profesionalisme guru sesuai bidangnya dan dapat berkontribusi dalam meningkatkan kinerja pembelajaran. (Hakim, 2015).

\section{KAJIAN TEORI \\ Kompetensi Profesional}

Untuk menjadi kompeten dalam profesi berarti: dapat menerapkan informasi khusus; menganalisis dan membuat keputusan; menggunakan kreativitas; dapat bekerja dengan orang lain sebagai anggota dalam sebuah tim; berkomunikasi secara efisien; dapat beradaptasi dengan lingkungan tempat kerja; dapat mengatasi situasi yang tak terduga. Kompetensi dibuktikan melalui pengetahuan yang solid, melalui keterampilan dan kemampuan untuk menggunakannya dalam mengembangkan aktivitas tertentu dan untuk mendapatkan hasil yang berhasil dihargai oleh yang lain (Mihaela, 2014)

Kompetensi profesional mencakup berbagai kemampuan yang harus dimiliki oleh seseorang terkait dengan profesionalismenya dalam pekerjaan. Dalam Undang-undang No. 14 tahun 2005, dijelaskan bahwa "Kompetensi Profesional adalah kemampuan penguasaan materi pelajaran secara luas dan mendalam". Budiwati dan Permana (2010) mengemukakan bahwa "Kompetensi Profesional merupakan kemampuan yang berkenaan dengan penguasaan materi pembelajaran bidang studi ekonomi secara luas dan mendalam yang mencakup penguasaan substansi isi materi kurikulum 
mata pelajaran ekonomi di sekolah dan substansi keilmuan yang menaungi materi kurikulum tersebut, serta menambah wawasan keilmuan sebagai guru".

Secara lebih rinci, Budiwati dan Permana, (2010) menjelaskan masingmasing kompetensi tersebut kedalam subkompetensi dan indikator esensial yaitu: a) Menguasai substansi keilmuan yang terkait dengan bidang studi ekonomi. Subkompetensi ini memiliki indikator esensial : memahami materi ajar yang ada dalam kurikulum sekolah, memahami struktur, konsep, dan metode keilmuan yang menaungi atau koheren dengan materi ajar; memahami hubungan konsep antar mata pelajaran terkait ; dan menerapkan konsepkonsep keilmuan dalam kehidupan seharihari. b) Menguasai langkah-langkah penelitian dan kajian kritis untuk menambah wawasan dan memperdalam pengetahuan/materi bidang studi ekonomi. Salah satu tugas guru sebagai agen pembelajaran adalah merancang pembelajaran, termasuk di dalamnya merancang materi pembelajaran. Materi yang tercantum dalam kurikulum dan silabus hanya merupakan acuan atau pedoman dasar.

\section{Kompetensi Pedagogik}

Peraturan Pemerintah Nomor 74 Tahun 2008 pasal 3 ayat 4 ditetapkan bahwa kompetensi pedagogik adalah kemampuan guru dalam pengelolaan pembelajaran peserta didik. Dalam kompetensi pedagogik, minimal terdapat beberapa aspek yang harus dimiliki oleh seorang guru, (Barnawi dan Arifin, 2012) diantaranya: 1) Pemahaman wawasan atau landasan kependidikan, Wawasan yang luas dan mendalam akan memudahkan guru untuk mengambil keputusan yang tepat dalam menentukan tindakan pendidikan. keputusan yang tepat akan meminimalisasi kesalahan guru (malpraktik) dalam menangani peserta didiknya. 2) Pemahaman terhadap peserta didik, terdapat dua hal yang harus dipahami guru dari peserta didiknya guna memahami karakteristik dari peserta didik itu sendiri, diantaranya yaitu kecakapan dan kepribadian. Berkaitan dengan kecakapan, ada peserta didik yang cepat menerima pelajaran dan ada yang lambat dalam belajar. Dari segi kepribadian, akan banyak ditemui kepribadian peserta didik yang khas dan unik. 3) Pengembangan kurikulum atau silabus. Kurikulum merupakan seperangkat rencana dan pengaturan mengenai tujuan, isi, dan bahan pelajaran, serta cara yang digunakan sebagai pedoman penyelenggaraan kegiatan pembelajaran untuk mencapai tujuan pendidikan tertentu. 4) Pengelolaan pembelajaran. Kemampuan dalam mengelola pembelajaran merupakan puncak dari kemampuan seorang pendidik. Dalam pembelajaran, guru hendaknya menciptakan hubungan sosio-emosional yang baik. Guru menyayangi dan mengayomi siswanya, siswa pun menghormati dan menaati gurunya. Keduanya harus saling menghormati dan menghargai sehingga pembelajaran dapat berlangsung efektif dan menyenangkan. Pengelolaan pembelajaran setidaknya mengandung kegiatan yang berupa perencanaan, pelaksanaan, evaluasi, dan tindak lanjut dari evaluasi.

\section{Kinerja}

Kinerja menurut Wirawan (2009), adalah keluaran yang dihasilkan oleh fungsifungsi atau indikator-indikator suatu pekerjaan atau suatu profesi dalam waktu tertentu. Secara umum dimensi kinerja dapat dikelompokkan menjadi tiga jenis, yaitu: hasil kerja, perilaku kerja, dan sifat pribadi yang berhubungan dengan pekerjaan, sedangkan Mangkunegara (2009) mengemukakan bahwa kinerja SDM merupakan istilah yang berasal dari kata Job Performance atau Actual Performance (prestasi kerja atau prestasi sesungguhnya yang dicapai seseorang). Kinerja karyawan 
(prestasi kerja) adalah hasil kerja secara kualitas dan kuantitas yang dicapai oleh seseorang karyawan dalam melaksanakan tugasnya sesuai dengan tanggung jawab yang diberikan kepadanya. Oleh karena itu, disimpulkan bahwa kinerja SDM adalah prestasi kerja atau hasil kerja (output) baik kualitas maupun kuantitas yang dicapai SDM persatuan periode waktu dalam melaksanakan tugas kerjanya sesuai dengan tanggung jawab yang diberikan kepadanya. Kinerja merupakan suatu kondisi yang harus diketahui dan dikonfirmasikan kepada pihak tertentu untuk mengetahui tingkat pencapaian hasil suatu instansi dihubungkan dengan visi yang diemban suatu organisasi atau perusahaan serta mengetahui dampak positif dan negatif dari suatu kebijakan.

Gibson, et al., (2000) membuat model teori kinerja dan melakukan analisis terhadap sejumlah variabel yang mempengaruhi perilaku dan kinerja individu. Pertama adalah variabel individu yang dikelompokkan pada sub variabel kemampuan dan ketrampilan merupakan faktor utama yang mempengaruhi perilaku dan kinerja individu, sedangkan variabel demografi mempunyai efek tidak langsung pada praktik dan kinerja individu. Kedua adalah variabel psikologi, terdiri dari sub variabel persepsi, sikap, kepribadian, belajar dan motivasi. Variabel ini menurut Gibson, et al., (2000) banyak dipengaruhi oleh keluarga, tingkat sosial, pengalaman kerja sebelumnya dan variabel demografi. Variabel ketiga adalah organisasi yang berefek tidak langsung terhadap perilaku dan kinerja individu, variabelnya dikelompokkan dalam sub variabel sumber daya, kepemimpinan, imbalan, struktur dan desain pekerjaan.

\section{Pengembangan Hipotesis}

Menurut Spencer \& Spencer (1993), kompetensi merupakan karakteristik dasar perilaku individu yang berhubungan dengan kriteria acuan efektif dan atau kinerja unggul di dalam pekerjaan atau situasi. Karakteristik dasar yang dimaksud adalah bahwa kompetensi harus bersifat mendasar dan mencakuip kepribadian seseorang dan dapat memprediksikan sikap seseorang pada situasi tertentu yang sangat bervariasi dan pada aktivitas pekerjaan tertentu. Hubungan kausal berarti bahwa kompetensi dapat menyebabkan atau digunakan untuk memprediksikan performansi superior seseorang. Kriteria yang dijadikan acuan berarti bahwa kompetensi secara nyata akan memprediksikan seseorang yang bekerja dengan baik atau buruk sebagaimana terukur pada kriteria spesifik atau standar.

Kompetensi yang harus dimiliki oleh guru terdiri dari Kompetensi Profesional, Kompetensi Pedagogik, Kompetensi Sosial, dan Kompetensi Kepribadian (Rusman, 2012). Jika melihat kepada model kompetensi dengan performansi kerja tersebut di atas, kompetensi pedagogik dan kompetensi professional termasuk ke dalam karakteristik personal Knowledge dan Skill, sedangkan kompetensi Sosial dan Kompetensi Kepribadian termasuk ke dalam Trait dan Self Concept.

Kompetensi pedagogis akan berkaitan dengan tingkat pemahaman peserta didik, desain instruksional, dan implementasi pembelajaran diagnosis, evaluasi pembelajaran, perkembangan peserta didik dalam bentuk pengajaran pedagogis professional, sedangkan kompetensi profesional guru tercermin dalam tingkat pemahaman bahan ajar, kemampuan untuk memahami konsep dan keterkaitan dengan ilmu lainnya, penguasaan langkah-langkah dalam penelitian dan analisis kritis untuk mengeksplorasi bahan ajar dan menemukan pemecahan masalah yang dihadapi (Hakim, 2015), kedua kompetensi ini saling berkaitan dan memiliki peran penting dalam rangka meningkatkan kualitas kinerja pembelajaran.

Martinjak, (2015) mengemukakan bahwa dalam proses mencapai learning 
outcomes, diperlukan kesesuaian antara pemilihan model dan metode pembelajaran. Kemampuan menyesuaikan antara ketiga komponen tersebut terdapat dalam kompetensi pedagogik guru, atau dalam penelitiannya, disebutkan sebagai competence of psychological knowledge yang didalamnya mencakup kemampuan guru untuk memahami karakteristik siswa, motivasi, dan proses pembelajaran.

Guru merupakan salah satu unsur yang turut memegang peranan penting dalam sebuah proses pendidikan. Guru merupakan pendidik professional yang memiliki fungsi utama sebagai perencana (designer), pelaksana (implementer) dan penilai (evaluator) pembelajaran. Oleh karena itu, kinerja guru yang baik sangat diperlukan guna terciptanya pendidikan yang berkualitas. Kinerja guru dalam pembelajaran berkaitan dengan kemampuan guru dalam merencanakan, melaksanakan, dan menilai pembelajaran, baik yang berkaitan dengan proses maupun hasilnya (Mulyasa, 2011). Kinerja yang tinggi membutuhkan kemampuan/kompetensi yang tinggi dalam pelaksanaan tugas sehari-hari, sehingga hasil dari pemaparan di atas dapat digambarkan kerangka konseptual berikut:

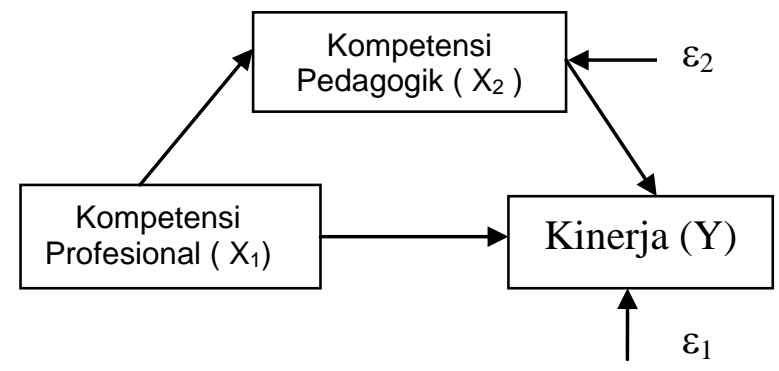

Gambar 1. Kerangka Konseptual

Dari kerangka analisis jalur yang terbentuk pada kerangka konseptual, hubungan antarvariabel dapat dibagi kedalam beberapa model sebagai berikut :

Model 1: $\mathrm{Y}=\mathrm{P}_{1} \mathrm{X}_{1}+\mathrm{P}_{2} \mathrm{X}_{2}+\varepsilon_{1} \ldots \ldots$ (1)

Model 2: $\mathrm{X}_{2}=\mathrm{P}_{1} \mathrm{X}_{1}+\varepsilon_{2}$
Hipotesis adalah kebenaran sementara yang ditentukan oleh peneliti, tetapi masih harus dibuktikan atau di tes atau di uji kebenarannya (Arikunto, 2006). Adapun hipotesis yang dirumuskan dalam penelitian ini: H1: Terdapat pengaruh positif antara kompetensi profesional terhadap kinerja guru. H2: Terdapat pengaruh positif antara kompetensi pedagogik terhadap kinerja guru. H3: Terdapat pengaruh positif antara kompetensi professional melalui kompetensi pedagogik terhadap kinerja guru

\section{METODE}

Metode yang digunakan dalam penelitian ini adalah metode survei eksplanatori. Penelitian survei menurut Kerlinger, (2006) adalah penelitian yang mengkaji populasi (atau universe) yang besar maupun yang kecil dengan menyeleksi serta mengkaji sampel yang dipilih dari populasi itu untuk menemukan insidensi, distribusi, dan interelasi relatif dari variabelvariabel sosiologis dan psikologis. Populasi dalam penelitian ini yaitu guru mata pelajaran ekonomi pada SMA Negeri di Kota Bandung sebanyak 117 orang, Teknik pengambilan sampel yang digunakan dalam penelitian ini yaitu dengan menggunakan rumus dari Taro Yamane: $n=N / n \cdot d^{2}+1$ (Riduwan, 2011), dimana $n=$ Jumlah sampel, $\mathrm{N}=$ Jumlah populasi, $\mathrm{d}^{2}=$ Presisi yang ditetapkan

Dalam penelitian ini diketahui jumlah populasi Guru Ekonomi SMA Negeri di Kota Bandung adalah sebesar 117 orang, sedangkan tingkat presisi yang ditetapkan adalah sebesar 5\%. Adapun jumlah sampel dalam penelitian ini adalah sebagai berikut :

$$
n=\frac{117}{117 \times(0,05)^{2}+1}=\frac{117}{(117 \times 0,0025)+1}=\frac{117}{1,2925}=90,5 \approx 90
$$

Setiap sekolah memiliki jumlah guru ekonomi yang berbeda satu sama lain, oleh karena itu dilakukan kembali pengambilan sampel penelitian untuk masing-masing 
sekolah. Sampel yang di ambil dari masingmasing sekolah adalah 2 sampai 6 orang guru per sekolah.

Untuk mengetahui hubungan antarvariable dengan mengetahui pengaruh langsung dan tidak langsung antara variabel kompetensi professional, kompetensi pedagogik, dan kinerja guru, maka digunakan pengujian path analysis (analisis jalur). Analisis jalur adalah metode analisis data multivariat dependensi yang digunakan untuk menguji hipotesis hubungan asimetris yang dibangun atas dasar kajian teori tertentu, dengan tujuan untuk mengetahui pengaruh langsung dan tidak langsung seperangkat variabel penyebab terhadap variable akibat yang dapat diobservasi secara langsung (Kusnendi, 2008). Alat bantu analisis yang digunakan dengan menggunakan software SPSS versi 20.

\section{HASIL DAN PEMBAHASAN Hasil}

Secara keseluruhan, deskripsi skor variabel Kompetensi Profesional, Kompetensi Pedagogik, dan Kinerja guru dapat dilihat sebagai berikut :

Tabel 1. Deskripsi Variabel Kompetensi Profesional

\begin{tabular}{lrrrrr}
\hline \multicolumn{1}{c}{ Variabel } & $\begin{array}{c}\text { Skor } \\
\text { Minimum }\end{array}$ & $\begin{array}{c}\text { Skor } \\
\text { Maximum }\end{array}$ & \multicolumn{1}{c}{ Total } & Rata-rata & $\begin{array}{c}\text { Simpangan } \\
\text { Baku }\end{array}$ \\
\hline $\begin{array}{l}\text { Kompetensi Profesional } \\
\left(X_{1}\right)\end{array}$ & 41.00 & 70.00 & 4845.00 & 53.8333 & 4.53761 \\
$\begin{array}{l}\text { Kompetensi Pedagogik } \\
\left(X_{2}\right)\end{array}$ & 88.00 & 150.00 & 10247.00 & 113.856 & 10.07563 \\
$\begin{array}{l}\text { Kinerja } \\
(Y)\end{array}$ & 55.00 & 83.00 & 6553.00 & 71.1556 & 5.36093 \\
\hline
\end{tabular}

Sumber : Hasil Penelitian

Skor terendah yang dicapai responden untuk variabel Kompetensi Profesional guru adalah sebesar 41, sedangkan skor tertinggi yaitu sebesar 70. Adapun rata-rata responden mendapatkan skor 53,83 dengan simpangan baku sebesar 4,54. Kompetensi Profesional Guru Ekonomi SMA Negeri di Kota Bandung tergolong Tinggi Karena $73,3 \%$ jawaban responden ada pada rentang 52-70. Sebesar $26.7 \%$ responden menyatakan Kompetensi Profesional guru Ekonomi tergolong kategori sedang yakni pada rentang 33-51.

Untuk variabel Tingkat Kompetensi Pedagogik terdiri dari 30 pertanyaan, oleh karena itu apabila responden menjawab pertanyaan secara lengkap maka skor maksimum yang akan didapatkan adalah sebesar 13500. Berdasarkan hasil penelitian, diketahui bahwa skor pernyataan mengenai Kompetensi Pedagogik guru secara keseluruhan adalah sebesar 10247 (75,9\%). Skor terendah yang dicarpai responden untuk variabel tingkat Kompetensi Pedagogik Guru Ekonomi SMA Negeri di Kota Bandung adalah sebesar 88, sedangkan skor tertinggi yaitu sebesar 150. Adapun rata-rata responden mendapatkan skor 113.856 dengan simpangan baku sebesar 10,07. Kompetensi Pedagogik Guru Ekonomi SMA Negeri di Kota Bandung tergolong tinggi Karena $66.7 \%$ jawaban responden ada pada rentang 110-150. Sebesar $33.3 \%$ responden menyatakan Tingkat Kompetensi Pedagogik Guru Ekonomi SMA Negeri Kota Bandung tergolong kategori sedang yakni pada rentang 70-109.

Berdasarkan hasil penelitian, diketahui bahwa skor pernyataan mengenai tingkat kinerja guru secara keseluruhan adalah sebesar 6553 (80,9\%). Kinerja Guru 
Ekonomi SMA Negeri di Kota Bandung tergolong tinggi Karena $90 \%$ jawaban responden ada pada rentang 66-90. Sebesar $10 \%$ responden menyatakan Kinerja Guru Ekonomi SMA Negeri Kota Bandung tergolong kategori sedang yakni pada rentang 42-65. Skor terendah yang dicarpai responden untuk variabel tingkat Kinerja Guru Ekonomi SMA Negeri di Kota Bandung adalah sebesar 55, sedangkan skor tertinggi yaitu sebesar 83. Adapun rata-rata responden mendapatkan skor 71,15 dengan simpangan baku sebesar 5,36.

Tahapan selanjutnya yang dilakukan yaitu uji signifikansi melalui uji - t statistik. Adapun hasil yang didapat dari uji t pada masing-masing model penelitian dengan bantuan software SPSS 20 adalah sebagai berikut :

\section{Pengujian terhadap Model I}

Untuk melakukan pengujian secara individual terhadap masing-masing variabel penelitian, hipotesis yang dirumuskan adalah: $\mathrm{H}_{1}$ : Terdapat Pengaruh Positif Kompetensi Profesional terhadap Kinerja Guru, $\mathrm{H}_{2}$ : Terdapat Pengaruh Positif Kompetensi Pedagogik terhadap Kinerja Guru

Kemudian dilakukan yaitu uji signifikansi melalui uji - t statistik. Adapun hasil yang didapat dari uji t dengan bantuan software SPSS 20 adalah sebagai berikut :

Tabel 2. Hasil Uji t

\begin{tabular}{cccc}
\hline Model & Koefisien Beta & Nilai t & Sig. \\
\hline$X_{1} \rightarrow Y$ & 0,444 & 3.532 & 0,001 \\
$X_{2} \rightarrow Y$ & 0,303 & 2.409 & 0,018 \\
\hline
\end{tabular}

\section{Sumber : Hasil Penelitian}

Dari Tabel 2 terlihat bahwa nilai t yang diperoleh adalah sebesar 3,532 dengan probabilitas sebesar 0,001 . Nilai probabilitas tersebut lebih kecil dari 0,05, maka Ho ditolak dan $\mathrm{H}_{1}$ diterima. Artinya, Kompetensi Profesional berpengaruh terhadap Kinerja Guru. Adapun koefisien jalur yang didapatkan yakni 0,444 , artinya variabel kompetensi professional mempengaruhi kinerja guru sebesar 44,4\% . Sedangkan untuk Kompetensi Pedagogik, dengan koefisien jalur 0,303 artinya variabel kompetensi pedagogik berpengaruh terhadap kinerja guru sebesar $30,3 \%$. Nilai Adj $\mathrm{R}^{2}$ yang diperoleh adalah sebesar 0,492 sehingga didapatkan residual dari koefien jalur dengan rumus $\sqrt{ }\left(1-R^{2}\right)=1-0,492=$ 0,713 (selanjutnya nilai ini dimasukkan ke dalam model sub struktur 1). Jadi persamaannya adalah $\mathrm{Y}=\mathrm{P}_{1} \mathrm{X}_{1}+\mathrm{P}_{2} \mathrm{X}_{2}+\varepsilon_{1}$ , menjadi $\mathrm{Y}=0,444 \mathrm{X}_{1}+0,303 \mathrm{X}_{2}+0,713$, dapat dilihat dalam gambar di bawah ini:

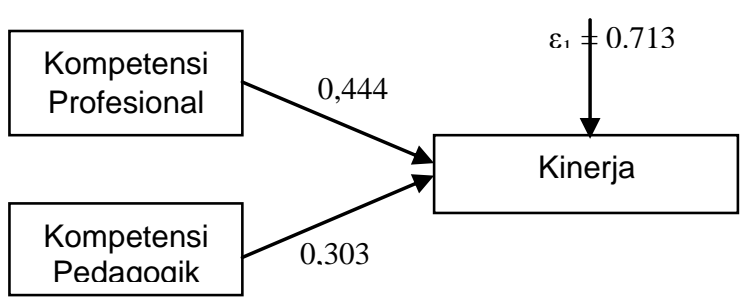

Gambar 2. Model Sub - Struktur I Sumber : Hasil Penelitian

\section{Pengujian terhadap Model II}

Untuk melakukan pengujian secara individual terhadap masing-masing variabel penelitian, sebelumnya perlu dirumuskan hipotesis terlebih dahulu. Adapun hipotesis yang dirumuskan adalah $\mathrm{H}_{3}$ : Terdapat pengaruh positif antara kompetensi professional melalui kompetensi pedagogik terhadap kinerja guru, tahapan selanjutnya yang dilakukan yaitu uji signifikansi melalui uji t statistik. Adapun hasil yang didapat dari uji $\mathrm{t}$ dengan bantuan software SPSS 20 adalah sebagai berikut : 
Tabel 3. Hasil Uji t

\begin{tabular}{cccc}
\hline Model & Koefisien Beta & Nilai t & Sig. \\
\hline $\mathrm{X}_{1} \rightarrow \mathrm{X}_{2}$ & 0,799 & 12,482 & 0,000 \\
\hline Sumber $:$ Hasil Penelitian & &
\end{tabular}

Dari Tabel 3 terlihat bahwa nilai $\mathrm{t}$ yang diperoleh adalah sebesar 12,482 dengan probabilitas sebesar 0,000. Nilai probabilitas tersebut lebih kecil dari 0,05, maka Ho ditolak dan $\mathrm{H}_{1}$ diterima. Artinya, Kompetensi Profesional berpengaruh terhadap Kompetensi Pedagogik. Koefisien jalur yang didapat adalah sebesar 0.799, artinya variabel Kompetensi Profesional mempengaruhi Kompetensi Pedagogik sebesar 79,9\%. Nilai Adj $\mathrm{R}^{2}$ yang diperoleh adalah sebesar 0,635 sehingga didapatkan residual dari koefien jalur dengan rumus $\sqrt{ }\left(1-R^{2}\right)=0,614$ (selanjutnya nilai ini dimasukkan ke dalam model sub struktur 1). Jadi persamaannya adalah $\mathrm{X}_{2}=\mathrm{P}_{1} \mathrm{X}_{1}+\varepsilon_{2}$, menjadi $\mathrm{Y}=0,799 \mathrm{X}_{1}+0,614$, dapat dilihat pada gambar berikut:

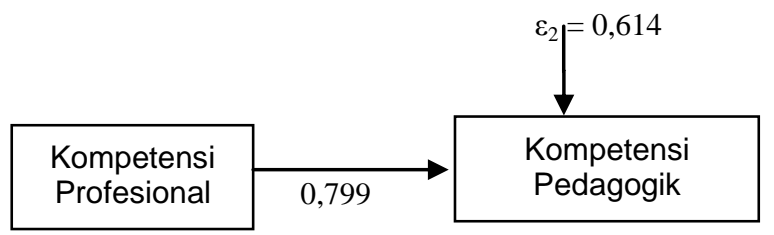

\section{Gambar 3. Model Sub - Struktur II}

\section{Analisis Jalur pada Masing-masing Variabel Penelitian}

Setelah dilakukan analisis data pada masing-masing model penelitian, hasil dari penghitungan terhadap masing-masing model dapat dirangkum pada tabel berikut ini :

Tabel 4. Dekomposisi Antar variabel Penelitian

\begin{tabular}{lcc}
\hline \multicolumn{1}{c}{ Model } & Koefisien Beta & Sig. \\
\hline$X_{1} \rightarrow Y$ & 0,444 & 0,001 \\
$X_{2} \rightarrow Y$ & 0,303 & 0,018 \\
$X_{1} \rightarrow X_{2}$ & 0,799 & 0,000 \\
\hline
\end{tabular}

Sumber : Hasil Penelitian

Dari Tabel 4 terlihat bahwa probabilitas thitung sebesar 0,001. Nilai probabilitas tersebut lebih kecil dari 0,05, maka Ho ditolak dan $\mathrm{H}_{1}$ diterima. Artinya, Kompetensi Profesional berpengaruh terhadap Kinerja Guru. Adapun koefisien jalur yang didapatkan yakni 0,444 , artinya variabel kompetensi professional mempengaruhi kinerja guru secara langsung sebesar 44,4\%.

Pada tabel 3 juga terlihat bahwa nilai probabilitas $\mathrm{t}$ hitung yang didapat untuk hipotesis 2 adalah sebesar 0,028. Nilai probabilitas tersebut lebih kecil dari 0,05, maka Ho ditolak dan $\mathrm{H}_{1}$ diterima. Artinya, Kompetensi Pedagogik berpengaruh terhadap Kinerja Guru. Koefisien jalur yang didapat adalah sebesar 0.303, artinya variabel kompetensi pedagogik mempengaruhi kinerja guru sebesar 30,3\%.

Dari hasil analisis jalur ditemukan pula pengaruh secara tidak langsung dari variabel Kompetensi Profesional melalui Kompetensi Pedagogik terlebih dahulu terhadap Kinerja guru yaitu sebesar 0,799 x $0,303=0,242$. Artinya, kompetensi professional mempengaruhi kinerja guru melalui variabel kompetensi pedagogik 
sebesar 24,2\%. Untuk mengetahui hubungan antar jalur penelitian dapat dilihat pada gambar berikut ini :

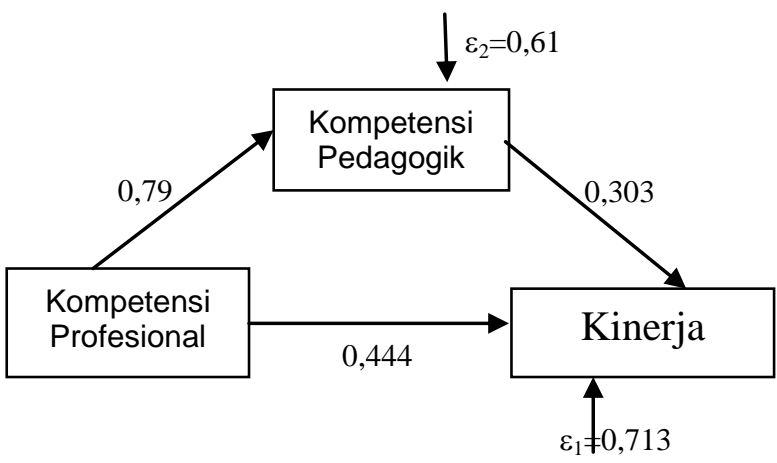

Gambar 3. Model Analisis Jalur Keseluruhan

\section{Pembahasan}

Kompetensi Profesional terhadap Kinerja Guru

Semakin tinggi kompetensi professional guru maka akan semakin tinggi pula kinerja guru yang bersangkutan. Kompetensi profesional adalah kompetensi atau kemampuan yang berhubungan dengan penyelesaian tugas-tugas keguruan. Kompetensi ini sangat penting karena berhubungan dengan kinerja yang akan ditampilkan, oleh karena itu tingkat keprofesionalan guru dapat dilihat dari kompetensinya. Kompetensi professional berhubungan dengan penyelesaian tugastugas keguruan. Kompetensi ini merupakan kompetensi yang sangat penting.

Guru yang memiliki skor kompetensi profesional yang tinggi ada kecenderungan mendapatkan skor kinerja guru yang tinggi. Dengan demikian, khusus kompetensi profesional guru mengenai penguasaan materi, struktur, konsep dan pola pikir keilmuan yang mendukung mata pelajaran yang diampu, mengetahui standar kompetensi dan kompetensi dasar mata pelajaran yang diampu, mengembangkan materi pembelajaran secara kreatif, mampu mengembangkan keprofesionalan secara berkelanjutan dengan melakukan refleksi, memanfaatkan teknologi informasi untuk mengembangkan diri.

Hasil yang ditemukan sejalan dengan penelitian Hakim (2015) yang mengemukakan bahwa kompetensi professional memiliki pengaruh positif terhadap kinerja guru. Hasil penelitian ini juga sejalan dengan penelitian Rahman (2014) yakni kualitas guru dapat dilihat dari penguasaan guru di bidang subjek dan kemampuannya dalam mengelola substansi pembelajaran akademis dan mengembangkan potensinya. Peran seorang guru sangat strategis dalam hal proses belajar mengajar karena ia atau dia akan membawa konsekuensi dalam melaksanakan tugasnya secara professional. Guru adalah dasar dari semua pendidikan, oleh karena itu, ini adalah tugas utama negara manapun yang harus memberikan perhatian tertinggi dan upaya tertinggi dalam menghasilkan guru yang berkualitas. Untuk mencapai hal tersebut, negara harus memberi kesempatan yang luas bagi pendidik guru dan guru agar memiliki kompetensi profesional dan menerapkan etika profesional. (Kulshrestha dan Pandey, 2013)

Di Kota Bandung, pengembangan kompetensi professional guru sudah seringkali dilakukan baik melalui sekolah masing-masing maupun secara berkelompok melalui pemberdayaan Musyawarah Guru Mata Pelajaran (MGMP). Termasuk dalam mata pelajaran ekonomi, program pengambangan kompetensi guru ini dilakukan secara berkala secara berkelompok melalui MGMP.

\section{Kompetensi Pedagogik terhadap Kinerja Guru}

Semakin tinggi kompetensi pedagogk guru maka akan semakin tinggi pula kinerja guru yang bersangkutan. Hasil yang ditemukan sejalan dengan penelitian Hakim (2015) yang mengemukakan bahwa kompetensi professional memiliki pengaruh positif terhadap kinerja guru.Mulyasa 
(2011) mengatakan kompetensi pedagogik sangat penting karena menjadi penentu bagi keberhasilan proses belajar yang langsung menyentuh kemampuan pembelajaran meliputi pengelolaan peserta didik, perencanaan, perencangan pelaksanaan, evaluasi hasil belajar dan pengembangan peserta didik terhadap potensi yang dimilikinya. Indikator dari kompetensi ini diantaranya 1) menguasai karakteristik peserta didik, 2) menguasai teori belajar, 3) mengembangkan

kurikulum, 4)menyelenggarakan pembelajaran, 5) memanfaatkan teknologi informasi, 6) mengembangkan potensi peserta didik, 7) berkomunikasi secara efektif, 8) melaksanakan penilaian, 9)memanfaatkan hasil penilaian untuk kepentingan pembelajaran, serta 10) melakukan tindakan reflektif".

Hasil yang ditemukan sejalan dengan penelitian Hakim (2015) yang mengemukakan bahwa kompetensi pedagogik memiliki pengaruh positif terhadap kinerja guru. Suciu dan Mata (2011) dalam penelitiannya pun mengemukakan bahwa kompetensi pedagogik dapat ditemukan secara konkret dengan subkategori lainnya, seperti kompetensi komunikasi dan hubungan atau manajemen kelas. Melalui pendekatan holistik dapat dibedakan antara kompetensi pedagogis umum, seperti kompetensi metodologi dan penilaian dan keterampilan khusus yang sesuai dengan kategori lain, seperti teknologi informasi, manajemen kelas, manajemen karir. Hal ini dapat dipahami bahwa ketika seseorang memiliki kompetensi pedagogik yang mumpuni maka wawasannya akan semakin bertambah. Disisi lain pola pikirnya juga akan berubah kearah yang positif. Dengan demikian kinerja juga akan semakin menigkat seiring dengan meningkatnya kompetensi pedagogik guru.

\section{Kompetensi Profesional melalui Kompetensi Pedagogik terhadap Kinerja Guru}

Hasil penelitian menunjukkan terdapat pengaruh kompetensi professional terhadap kinerja guru melalui variabel kompetensi pedagogik. Hasil yang didapatkan ini sejalan dengan penelitian Supriyatno, et al., (2016) yang mengemukakan bahwa kompetensi guru dapat meningkatkan Kinerja Guru. Selain itu, penelitian Bintarti (2017) mengemukakan bahwa tingkat kompetensi memiliki hubungan positif yang cukup dengan kinerja tenaga pendidik. Juga penelitian Hafid, (2017) yang menyatakan bahwa Kompetensi Guru memiliki pengaruh positif terhadap kinerja guru. Sebagaimana dikemukakan dalam penelitian Selvi, (2010) bahwa, "Tujuan Pendidikan seringkali berubah-ubah sesuai dengan tuntutan zaman yang membutuhkan kemampuan jauh lebih banyak. Tuntutan inilah yang mempengaruhi system Pendidikan secara keseluruhan. Guru bertanggungjawab dalam menjalankan system Pendidikan dan mereka membutuhkan kompetensi professional yang kuat dan efisien". Untuk meningkatkan kemampuan dalam menjalankan system Pendidikan yang cenderung berubah-ubah ini, atau yang biasanya dikenal sebagai kompetensi pedagogik, dibutuhkan pula kompetensi professional yang tiggi dari masing-masing guru yang bersangkutan. Hasil penelitiannya tersebut, mengindikasikan bahwa kompetensi professional guru mencakup empat kelompok kompetensi yakni kompetensi kurikulum, kompetensi belajar sepanjang hayat, kompetensi sosial-kultural, dan kompetensi emosional.

\section{SIMPULAN}

Kompetensi Profesional berpengaruh terhadap Kinerja guru. Artinya, semakin tinggi Kompetensi Profesional guru maka akan semakin tinggi pula Kinerja guru Ekonomi di Kota Bandung. Hasil penelitian 
di lapangan menunjukkan bahwa kompetensi professional guru menentukan penguasaan materi guru ketika mengajar di dalam kelas. Semakin kompeten penguasaan materi guru yang bersangkutan, maka performa guru di kelas pun semakin baik. Khususnya untuk mata pelajaran ekonomi, dimana materi yang harus dikuasai oleh guru tidak hanya bersifat konseptual namun juga sebagian terdapat materi-materi yang bersifat analitis dan juga matematis. Oleh karena itu, peningkatan kompetensi professional guru ekonomi secara berkelanjutan harus ditingkatkan dan diperlukan dukungan dari berbagai pihak terkait baik dari pemerintah, dinas Pendidikan, maupun sekolah tempat guru bekerja masing-masing.

Kompetensi Pedagogik berpengaruh terhadap Kinerja guru. Artinya, semakin tinggi Kompetensi Pedagogik guru maka akan semakin tinggi pula Kinerja guru Ekonomi di Kota Bandung. Temuan di lapangan menunjukkan bahwa kompetensi pedagogik guru memperlihatkan kemampuan guru terkait teknik pembelajaran di dalam kelas. Semakin kompeten secara pedagogik, maka penguasaan kelas guru pun semakin tinggi. Hal ini yang dapat mempengaruhi kinerja guru di dalam kelas. Oleh karena itu, program-program peningkatan kompetensi professional guru harus ditingkatkan lagi agar kinerja guru pun semakin meningkat.

\section{REFRENSI}

Arikunto, S. (2006). Prosedur Penelitian: Suatu Pendekatan Praktik.

Barnawi dan Arifin, M. (2012) . Etika Profesi Keguruan. Jogjakarta: ArRuzz Media

Bintarti, Surya (2017). Studi Tentang Tingkat Kompetensi Dan Budaya Organisasi Terhadap Kinerja Tenaga Pendidik SMPIT Pesantren Al Binaa Bekasi Tahun 2016. Value Journal of Management and Business, 1(2),
Budiwati, N., dan Permana, L. (2010). Perencanaan Pembelajaran Ekonomi. Bandung: Universitas Pendidikan Indonesia

Kerlinger, F, N. (2006). Asas-asas Penelitian Behavioral. Yogyakarta: UGM

Gibson.J.I, Ivancevich, J.M. \& Donelly. J. H. (2000). Organisasi Perilaku: Struktur dan Proses. Jilid 2, Edisi 8. Jakarta: Bina Rupa Aksara

Hafid, M. (2017). Pengaruh Motivasi Dan Kompetensi Guru Terhadap Kinerja Guru Sekolah Dan Madrasah Di Lingkungan Pondok Pesantren Salafiyah Syafi'iyah Sukorejo. Jurnal Pendidikan Islam Indonesia (JPII). 1(2), 293-314.

Hakim, A. (2015). Contribution of Competence Teacher (Pedagogical, Personality, Professional Competence and Social) On the Performance of Learning. The International Journal Of Engineering And Science (IJES), 4(2), 1-12.

Kulshrestha, A.K dan Pandey, K. (2013). Teachers Training and Professional Competencies. Voice of Research, 1(4), 29-33.

Kusnendi. (2008). Analisis Jalur: Konsep dan Aplikasi dengan Program SPSS dan Lisrel 8. Bandung: Universitas Pendidikan Indonesia.

Mangkunegara, A. P. (2009). Evaluasi Kinerja SDM. Bandung: PT. Refika Aditama.

Martinjak, Natasa Zrim. (2015). Developing Pedagogical Competency During Teacher Through the Experiential Learning of Didactic and Metodhological Approaches. PeF Prints: University of Ljubljana Faculty of Education

Mihaela, P, L. (2014). Dimensions of Teaching Staff Professional Competences. Procedia - Social and Behavioral Sciences, 2015, 924 - 929. 
Mulyasa, E. (2011). Uji Kompetensi dan Penilaian Kinerja Guru. Jakarta: PT Remaja Rosdakarya.

Peraturan Pemerintah Republik Indonesia Nomor 74 Tahun 2008 tentang Guru. Lembaran Negara Republik Indonesia Tahun 2008. Jakarta

Permendiknas No. 16 Tahun 2007 Tentang Standar Kualifikasi Akademik dan Kompetensi Guru. Lembaran Negara Republik Indonesia Tahun 2007. Jakarta

Rahman, M, H. (2014). Professional Competence, Pedagogical Competence and the Performance of Junior High School of Science Teachers. Journal of Education and Practice, 5(9), 75-80

Riduwan. (2011). Cara Menggunakan dan Memakai Path Analysis. Bandung: Alfabeta.

Rusman.

(2012).

Model-kodel Pembelajaran: Mengembangkan Profesionalisme Guru. Jakarta: PT Raja Grafindo Persada

Selvi, K. (2010). Teacher's Competencies. Cultura. International Journal of Philosophy of Culture and Axiology, 7(1), 167-175

Spencer, Lyle M dan Spencer, Signe M. (1993). Competence at Work : Models For Superior Performance. Canada: John Wiley \& Sons Publishers

Suciu, A. I., dan Mata, L. (2011). Pedagogical Competences -The Key to Efficient Education. IOJES: International Online Journal of Educational Sciences, 3(2), 411-423

Supriyatno, A., Subiyanto., dan Tawil. (2016). Pengaruh Sertifikasi Pendidik, Kompetensi Guru Dan Kepemimpinan Kepala Sekolah Terhadap Kinerja Guru SMA. Jurnal Ikatan Sarjana Pendidikan Indonesia (ISPI) Jawa Tengah, 3(2), 171-181.

Undang-Undang Republik Indonesia No. 14 tahun 2005 tentang Guru dan Dosen.
2005. Lembaran Negara Republik Indonesia Tahun 2005. Jakarta.

Undang-Undang Republik Indonesia Nomor 20 Tahun 2003 Sistem Pendidikan Nasional. 8 Juli 2003. Lembaran Negara Republik Indonesia Tahun 2003 Nomor 4301. Jakarta.

Wirawan.(2009). Evaluasi Kinerja Sumber Daya Manusia. Jakarta: Salemba Empat. 